\title{
Ruminal fermentation modification of protein and carbohydrate by means of roasted and estimation of microbial protein synthesis
}

\author{
Héctor Andrade-Montemayor ${ }^{1 \#}$, Teresa García Gasca², Jorge Kawas ${ }^{3}$
}

\begin{abstract}
${ }^{1}$ Facultad de Ciencias Naturales, Universidad Autónoma de Querétaro, Cuerpo Académico de Morfofisiología Animal, Licenciatura en Medicina Veterinaria y Zootecnia ${ }^{1}$. Campus Juriquilla. Ave. De las Ciencias S/N, Juriquilla, Delegación Santo Rosa Jáuregui, Querétaro México. CP. 76230.\#Autor de Correspondencia: andrademontemayor@yahoo.com.mx.

2 Facultad de Ciencias Naturales, Universidad Autónoma de Querétaro, Cuerpo Académico de Biología Celular, Licenciatura en Nutrición. ${ }^{2}$ Campus Juriquilla. Ave. De las Ciencias S/N, Juriquilla, Delegación Santo Rosa Jauregui, Querétaro México. CP. 76230 Querétaro, México.

3 Centro de Investigaciones Agropecuarias. Facultad de Agronomía, Universidad Autónoma de Nuevo León, Avenida Francisco Villa S/N, Colonia Exhacienda El Canadá, Escobedo, Nuevo León, México. CP 66050
\end{abstract}

\begin{abstract}
The animal meal prohibition as a protein source with low ruminal degradability in ruminant nutrition, creates the need to seek alternatives, as legume seeds, however, its protein, have a high degradability, which could generate losses of nitrogen in the rumen. Other problem in the legume seeds is the content of antinutritional factors such as protease inhibitors, tannins, phenolic compounds, lectins and some others, could affect the digestibility. One alternative to decrease the degradability of the protein and / or decrease the activity of some antinutritional factors is the use of different technological treatments such as roasting. Microbial protein synthesis is dependent on the availability of nitrogen or amino acids and of the degradable carbohydrate content, or of content of Organic Matter digestible and rumen degraded (OMDRD), and the synchronization in rumen degradation between protein and carbohydrates. If there are high amounts of degradable nitrogen or if the content and rate of carbohydrates degradation in the rumen is reduced or not synchronized with the degradation of protein, could be losses of nitrogen and / or energy in the rumen. In this paper, we analyze the characteristics of proteins and carbohydrates from various seeds and grains, the effect of dry-roasted application on degradability behavior of seeds.
\end{abstract}

Key Words: carbohydrates, degradation, microbial protein synthesis, protein, roasted

\section{Modificação da fermentação ruminal de proteína e carboidrato por meio da tostagem e estimativa de síntese de proteína microbiana}

RESUMO - A proibição das farinhas de origem animal como fonte de proteína com baixa degradabilidade na nutrição de ruminantes, criou a necessidade de buscar alternativas, como sementes de leguminosas, porém, sua proteínas têm alta degradabilidade, podendo gerar perdas de nitrogênio no rúmen. Outro problema em sementes de leguminosas é o conteúdo de fatores antinutricionais, como os inibidores de proteases, taninos, compostos fenólicos, lectinas e alguns outros, podendo afetar a digestibilidade. Uma alternativa para diminuir a degradabilidade da proteína e/ou diminuir a atividade de alguns fatores antinutricionais é o uso de diferentes tratamentos tecnológicos, tal como a tostagem. A síntese de proteína microbiana é dependente da disponibilidade do nitrogênio e o conteúdo de carboidrato degradável, ou o conteúdo de matéria orgânica digestível e degradada no rúmen (MODR), e a sincronização da degradação no rúmen entre proteína e carboidratos. Se existem elevadas quantidades de nitrogênio degradável, ou se o conteúdo e a taxa de degradação de carboidratos no rúmen é reduzida ou não sincronizada com a degradação da proteína, pode-se perder nitrogênio e/ou energia do rúmen. Neste trabalho, foram analisadas as características das proteínas e carboidratos de várias sementes e grãos, o efeito da aplicação da tostagem seca no comportamento da degradabilidade das sementes.

Palavras-chave: carboidratos, degradação, proteína, síntese de proteína microbiana, tostagem

\section{Introduction}

Searching alternative energy and protein sources in ruminant feed has become a priority especially in developing countries or non-producers countries of soybeans, like Mexico, that produce only $4 \%$ of soybeans used in the production of animal feed (SAGARPA, 2006). On the other hand, the prohibition on the use of animal meal in animal feed, due to bovine spongiform encephalopathy, has limited the availability of protein sources with low degradability, needed in the feeding of high production ruminants (Andrade-Montemayor, 2005). 
There are a wide variety of regional legumes seed, which can be an alternative source of protein and starch; however, the use of legumes seed in ruminants is limited by its high content of soluble and degradable protein (Yu et al., 2002a). Cause an imbalance between the ruminal degradation of feed nutrients and microbial protein synthesis, resulting in loss of ruminal nitrogen. Moreover, legume seeds may have variable content of antinutritional factors such as lectins, condensed tannins, phenolic compounds, protease inhibitors, alkaloids, etc., which depends on the type of seed and its phenological state (Yu et al., 2002a; Makkar, 2003; Kreuzer, 2004; Bhatta et al., 2007). There are various treatments that may be reducing protein degradability and present different effects on the content and activity of antrinutritional factors, these treatment involve combinations of temperature, humidity and pressure, or only increase of temperature, dry roasting has shown their effectiveness in reducing the solubility, degradability and/ or protein degradation rate in the rumen, and modify the degradation of carbohydrates and the content or activity of certain antinutritional factors, and improve the nutritional value of legume seeds (Brenes and Brenes, 1993; Goelema et al. 1998; Goelema et al., 1999, Yu et al., 1999, Yu et al., 2000, Yu et al. , 2002a; Yu, 2007).

Microbial protein synthesis dependent of the relationship between the amount of soluble and degradable nitrogen or protein, as well as its rate of degradation, and the amount of digestible organic matter fermented in rumen (DOMFR) or carbon chains (CHO's ) available to rumen microorganisms, both sources of nitrogen and degradable CHO's must be in a synchronized way, both in quantity and rate of degradation, can be increase the microbial protein synthesis (INRA, 1988, Chen and Gomes, 1992; Tamminga et al. 1994, Andrade-Montemayor, 2004). Knowing the impact of thermal treatments such as dry roasting on the modification of protein and carbohydrates degradation, could handle used to manipulate the behavior of each legume seed, or grain, and stimulate the synthesis of microbial protein.

\section{Concept of degradedability}

Ruminal digestion is a dynamic process that is characterized by the entry of food in the rumen fluid, and output of fluids, microorganisms and not degraded food (Van Soest, 1994). The feed that the ruminant intake can be divided into two fractions: one undegradable fraction and other potentially degradable fraction, which is degraded by microorganisms to a certain speed or rate (Gonzalez et al., 1991).
The food fraction that is hydrolyzed in the rumen to provide energy (fermentable carbohydrates) or a peptides mixture, amino acids and ammonia (NNP and protein) for growth and synthesis of microbial protein, is defined as degradable fraction. Microbial protein provides the most of the amino acids that pass into intestine and contributing with 40 to $50 \%$ of the protein to ruminant (Goestch \& Owens, 1984). The remaining protein fraction that reaches intestine is the food protein that undegraded in rumen (UDP).

The ruminal degradation of food nutrients, is influenced by several factors, among them are: the characteristics of the diet, related to the amount of potentially degradable nutrients, the food intake level, the food residence time in rumen, and food exposure to the rumen microorganisms and environmental conditions in the rumen, such as $\mathrm{pH}$ and $\mathrm{NH}_{3}$ concentration, which depends on the activity and microbial survival (Ørskov, 1988).

\section{Ruminal digestion of protein}

The food nitrogen compounds (NPN and true protein) are exposed to rumen microbial enzymatic activity and are subjected to partial or total degradation. In general, the simple nitrogen compounds and highly soluble as the non protein nitrogen (NPN), are degraded by rumen microorganisms resulting in an increase in the $\mathrm{NH}_{3}$ rumen concentration. Furthermore, the proteins are partly degraded by the action of microorganisms proteolytic enzymes, resulting in peptides and amino acids, which by the action of peptidases and desaminase of these microorganisms, produce ammonia, volatile fatty acids (VFA) and carbon dioxide (Annison and Lewis, 1981; Balcells and Castrillo, 2002). The degradation of certain amino acids is related to the production of small quantities as branching AGV isobutyric and isovaleric acid (Yan et al., 1996). Ruminal microorganisms use ammonia, as well as some simple peptides and amino acids as nutrients for their own growth. When microorganisms cross the abomasum and small intestine, cellular proteins are digested and absorbed.

Thus, the rumen microorganisms play a determining activity in digestion and metabolism of nitrogenous compounds in ruminants. Bacterias are the most abundant microorganisms in the rumen, of which $40 \%$ or more have proteolytic activity. Intracellular events in the peptides and amino acids degradation by bacteria and microbial protein synthesis are:

- Peptides to aminoacids conversion;

- Use of free amino acids for protein synthesis;

- Amino acids catabolism to ammonia and carbon skeletons (desamination); 
- Ammonia use for the resynthesis of aminoacids;

- Ammonia out of the cell dissemination (Broderick, 1994).

Protozoa are very active in the protein degradation, protozoa population are fewer than rumen bacteria population (Ørskov, 1988). These microorganisms ingest bacteria, fungi, and portions of food and bacterias are their protein source.

\section{Protein degradation kinetic}

Nitrogen fractions in feed, have different susceptibility and route of degradation, as has been demonstrated in numerous studies (Zinn et al., 1981, Ha and Kennelly, 1984, Anderson et al., 2001). Figure 1 (INRA, 1988) is shown as depending on the type of food and degradation time, the degradation rate different.

Protein fractions of legume seeds such as peas have a high percentage of degradation in a short period of time, however fishmeal or heat treated cakes, have a lower levels of degradation.

\section{Non-structural carbohydrates degradability}

Non-structural carbohydrates can be digested by the ruminal microbial population and by the animal; because both organisms can produce enzymes capable of degrading non-structural polysaccharides such as starch to sugars (Hoover and Stokes, 1991). In the ruminant case such action occurs primarily in the rumen by the action of ruminal microorganisms.

Starch and dextrin digestion is carried out initially by the amylase action, which converts maltose and isomaltose, followed by enzymatic action of maltase, phosphorylase or 1,6-glucosidase to glucose or glucose-1 - phosphate. Fructans in turn has hydrolyzed by enzymes that attack the links 2-1 and 2-6 to fructose (Chesson and Forsberg, 1988).

Starch digestion from cereal grains or other concentrated, is complete in most ruminant. However, the degree and form of ruminal digestion of starch will be different, depending on the raw material, its processing and presentation (Nocek and Tamminga, 1991). These factors have very important consequences in the design of rations, being necessary to study these parameters. The degradation of soluble sugars is almost immediate (Baldwin and Allison, 1983), and the starch of cereals in most ruminant rations is complete (Blas et al., 1995). There are differences among different kinds of cereals, in the proportion of soluble starch (hydrolyzed very quickly), fermented in the rumen and digested in subsequent sections of the digestive system.

Starch from wheat and barley (as of cassava, bran or gluten feed) are characterized by a faster and complete

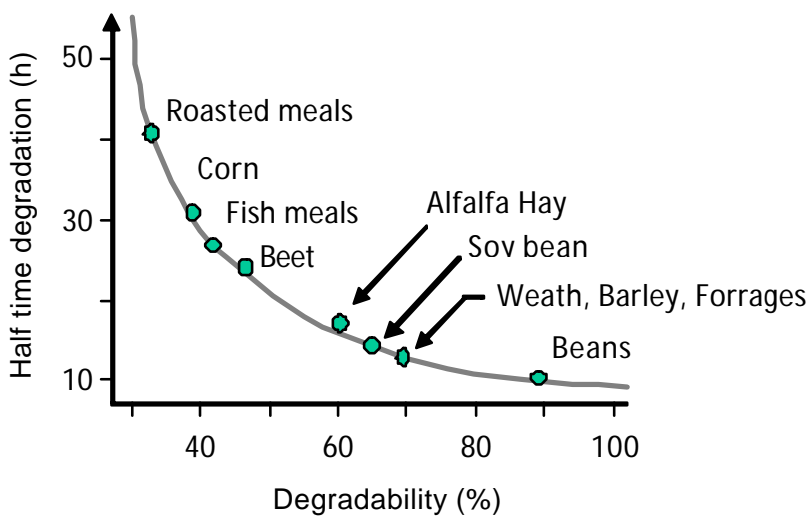

Figure 1 - Half time degradation and degradability of protein fractions (\%) of different feeds (INRA, 1988).

fermentation in the rumen that starch of corn or sorghum (Figure 2) (Sauvant et al., 1994). As a result, the first provides more energy available to rumen microorganisms, favoring the synthesis of microbial protein, but are also can be the cause problems of ruminal acidosis.

Just as there are differences in the starch degradation from cereal grains, other starches from various ingredients of rations for ruminants are characterized by different degraded parameters (Table 1) (Sauvant et al., 2003), which also can be modified by the treatments to which they are subjected.

Heat treatment and application of moisture, can change the starch structure, in the case of cereal starches, increased the ruminal degradability and in some legume seeds may decrease the starch ruminal degradation, by modifying the degradation rate $(\mathrm{kd})$, or increasing or decreasing the soluble fraction (a) and slow degradation fraction (b) (Yu et al., 2002a).

The carbohydrate degradation kinetics is very complex, and modern methods of assessment need a precise knowledge of the characteristics carbohydrates and proteins degradation, of seeds and grains use in animal rations, as well as the factors that affect them. Thus, the system of Sniffen et al. (1992) subdivided into four fractions of carbohydrates depending on their degradation rate:

$\mathrm{A}=$ very quickly rate of sugars degradation.

$\mathrm{B} 1$ = intermediate rate of degradation (pectins and starches)

B2 = fibrous carbohydrates of slow degradation and potentially degradable

$\mathrm{C}=$ indigestible fiber fraction.

New systems tend to increase the number of parameters that make up their equations (Calsamiglia \& Bach, 2002), to integrate new knowledge on the degradability of different carbohydrates fractions and 
Degraded starch \%

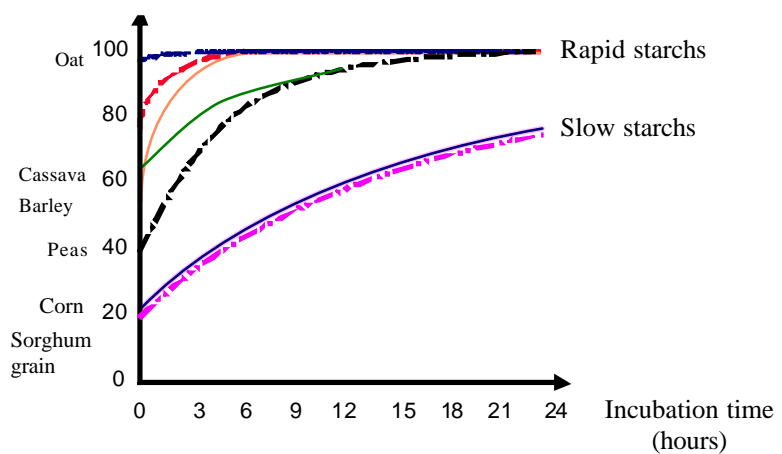

Figura 2 - Degradation kinetic of grains and root vegetables starch (Sauvant et al., 1994).

increase the accuracy of itsestimates on its nutritive value and performance in the rumen.

\section{Factors affecting the ruminal degradability}

There are many factors linked to food, as nitrogen and carbohydrate sources characteristics, can be considered as elements that will affect the rate of degradation in the rumen. There are other factors linked to animals that influence the nutrients rumen degradation.

\section{Structure of the protein molecule}

The three-dimensional structure of proteins is a factor that determines its rumen solubility and degradability. In general, for higher complexity and quantity of links, greater difficulty to accessing of microbial enzymes to the protein. For example, ovalbumin degrades slowly because is a cyclic protein which don't have amino or carboxyl terminal groups (NRC, 1985). Proteins with large amounts of crosslinks such as disulfide linkages are less accessible to proteolytic enzymes and are relatively resistant to degradation (Van Soest, 1982, Owens and Goestch 1984, Wallace, 1988; Balcells \& Castrillo, 2002).

\section{Solubility of protein in the rumen}

The classification of proteins in soluble and insoluble, has been of great importance in ruminant feed systems because, the soluble proteins provide more available nitrogen to the rumen microorganisms (Wallace, 1988, Van Soest, 1994, NRC, 2001). However, there is a clear relationship between the solubility of proteins and their degradability. In general, soluble proteins are more vulnerable to proteolysis that the insoluble proteins, the proteases accessibility increased if the protein is in solution. However, some proteins can be hydrolyzed in the solid state and being poorly soluble, as is the zein and casein case (NRC, 1985 and 2001), or in contrast, albumin is a soluble protein but very resistant toruminaldegradation (McDonald et al., 1995).

Mahadevan et al. (1980) concluded that the solubility of a protein is not an indicator of susceptibility to proteolysis. Stern and Satter (1984) analyzed of 34 different rations, and they noted a correlation of only 0.26 between $\mathrm{N}$ solubility and degradability of the protein in vivo.

\section{Protein and starch location and structure}

The protein and starch location in the grain, affecting its use and degradation, therefore, it is important to know the parts that constitute, and composition. As shown in Table 1, the starch degradability of the grains of different cereals and legumes is different, because of the starch location and structure of starch is different and characteristic for each type of grain. Thus, their differences between the starch degradability from cereal grains, which is high in wheat and barley, and much lower for corn or sorghum.

One element to consider is the type of peripheral area surrounding the endosperm where the starch. The endosperm of a grain of corn and sorghum is formed by a peripheral area (sub-aleurone), and a corneal and a meal area. The peripheral area of the endosperm is extremely

Table 1 - Starch degradability of different ingredients using in ruminant feeding (Sauvant et al., 2003)

\begin{tabular}{|c|c|c|c|c|c|}
\hline Ingredient & Starch of DM \% & $\mathrm{A}(\%)^{1}$ & $\mathrm{~b}(\%)^{2}$ & $\mathrm{c}(\% / \mathrm{h})^{3}$ & Effective degradability ${ }^{4}$ \\
\hline Oat & 36,2 & 67 & 33 & 21,5 & 93 \\
\hline Corn & 64 & 23 & 77 & 5,5 & 60 \\
\hline Corn granulate & 64 & 39 & 61 & 4,0 & 64 \\
\hline Barley & 52,2 & 52 & 48 & 20,5 & 89 \\
\hline Peas & 44,6 & 46 & 54 & 9,5 & 79 \\
\hline Roasted peas & 44,6 & 28 & 72 & 4,5 & 59 \\
\hline Extruded peas & 44,6 & 70 & 30 & 7,4 & 87 \\
\hline
\end{tabular}

$1 \mathrm{a}(\%)$ : Soluble fraction and of rapid degradation.

$2 \mathrm{~b}(\%)$ : Slow and potential degradation fraction.

${ }^{3} \mathrm{c}(\% / \mathrm{h})$ : rate of degradation $\mathrm{k}_{\mathrm{d}}$

${ }^{4}$ Effective degradation. 
dense and hard, and resistant to the ingress of water. The peripheral cells have a high content of protein resistant to enzymatic and physical degradation, resulting in a low degradability (Rooney and Pflugfelder, 1986; Kotarski et al., 1992).

The rate of ruminal degradation of the protein matrix, determines the rate of starch hydrolysis, because the starch surface, which is in contact with the amylases, increases as the matrix degrades. The vitreous nature of sorghum and maize is associated with its protein content and continuity of the protein matrix. These cereals have a lower proportion of soluble proteins (albumins and globulins) and a greater proportion of reserve proteins (prolamin and glutelin) that are less soluble and slow degradation (Blas et al., 1995).

Starch degradability from legumes is high, due to the starch type, its interaction with the protein matrix, and the lowest ratio of amylose-amylopectin (Nocek and Tamminga, 1991, Yu et al., 2000, 2001a, 2002a., Yu, 2007). Thus, the starch degradability, can be affected by the composition and physical form of starch, the proteins and starch interaction, the granule size, the amylose and amylopectin content and relation, the presence of the protein matrix, the starch type (corneum or flour), the cellular integrity of the starch units, anti-factors and the physical form of food or food material (Rooney \& Pflugfelder, 1986, Yu et al., 2002a; Offner et al., 2003).

\section{Treatment of raw materials}

Other factors affecting food degradability and its components in the rumen, as the treatments those different ingredients suffer before and during food processing.

The treatments can be divided into physical and chemical and their effects are dependent on the type of food and nutrient. But in this review only studies the effect of temperature and especially of dry roasted treatment on degradability of starch and protein.

\section{Heat treatment}

Heat treatments have different effects, depending on the degradability of the nutrient, so to divide the study of their effect of heat on starch or protein degradability.

\section{Heat treatment effects on starch degradability}

Starch is composed by grains insoluble in cold water, but with ability to absorb water and swell reversibly. These grains are pseudo-crystals that contain crystalline regions and amorphous unorganized areas. The crystalline area is very resistant to water infiltration, which moves freely in the amorphous areas.
The swelling of starch is a process that results from exposure to water and gradual warming $\left(55^{\circ} \mathrm{C}\right)$ of the grain, allowing it to absorb up to $50 \%$ of its weight in water. This swelling is reversible after cooling and drying, however, if more heat is applied $\left(60\right.$ to $\left.80^{\circ} \mathrm{C}\right)$, the process becomes irreversible, leading the gelatinization that is the loss of the crystalline structure of the grain. In the gelatinization, the starch grains are broken completely, and often the result of the combination of moisture, heat, pressure and physical and mechanical forces (Wiseman, 1993). Retrogradation is another process linked to the heat treatment, which is the re-association of separated molecules after the gelatinization. Hydrogen bonds between amylose and amylopectin are restored, however, the starch does not return to its original form. Retrogradation may be reversible to some extent after heating.

During the manufacture of feed raw materials are subjected to physical and mechanical forces arising from the application of moisture, heat and / or pressure, which can cause gelatinization or retrogradation. In any case, questions remain to be clarified, since it seems the effect of heat treatment on starch degradation depends on several factors such as temperature applied, treatment duration, application with or without humidity, type of seed, etc.

The variability in the effects of temperature and pressure toasting on the starch, may be due to the difference in the crystallization of starch and/or the association between starch and protein matrix surrounding the grains. Besides other factors may be involved as the proportion of amylose and amylopectin, the particle size and enzyme inhibitors ( $\mathrm{Yu}$ et al., 2002a).

Theurer et al. (1999) found that the humidity, temperature and pressure combination, consistently increased in vitro enzymatic hydrolysis of starch and the proportion of starch digested in the rumen of total digestible starches. These events were probably due to the disruption of the protein matrix surrounding the grains of starch in the endosperm and the disruption of these grains (Yu et al., 2002a).

Among the most common treatments according to $\mathrm{Yu}$ et al. (2002a) we find the following:

- Dry roasted. This treatment is done with dry heat that is transferred by conduction, convection and radiation. The moisture of the grain is adjusted before treatment and the temperature and time of application varies (100 to $200^{\circ} \mathrm{C}$ and 15 to 60 minutes). 
- Micronized. In this heat treatment is performed inside the seeds by means of infrared rays, the temperature is from 125 to $135^{\circ} \mathrm{C}$ with an exposure time of $40-90$ seconds. Infrared rays cause the vibration of the molecules in the material, resulting in the internal heating and moisture loss.

- Toasting pressurized. Make in pressurized container and combined heat and pressure, the time is very variable.

- Extrusion. This treatment combines heat by friction, pressure, humidity and breakup, followed by the expansion of the food. The processing time is 30 to 50 seconds, and the temperature ranges from 80 to $200^{\circ} \mathrm{C}$.

-Treatment of expansion (expander). This is similar than to extrusion, however, modifies the pressure with a cone hydraulic, 3800-4000 kPa of pressures are used during treatment. The treatment time is 5 to 15 seconds and temperatures of 80 to $140^{\circ} \mathrm{C}$.

- Granules (pellets). This process is a compression of the food, previously conditioned or treated, making it pass through a matrix. The packaging may be by addition of water steam, in relation to the amount of friction between food particles, and the wall and die. The conditioning is performed at a temperature of 65 to $90^{\circ} \mathrm{C}$.

As shown in Figure 3, the effect of extruded on the rate of starch degradation on corn and peas is different, as observed in the case of corn extrusion that increased rate of starch degradation, but in the pea case, the heat treatment decreases the rate of degradation of a very pronounced form.

Yu et al. (2002a) found that both the roasting pression and dry roasting decreased the starch effective degradability

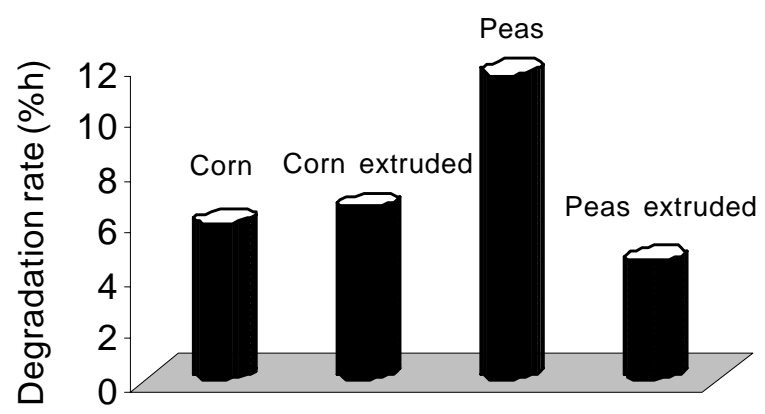

Figure 3 - Effect of extrution in starch rate of degradation $(\% / \mathrm{h})$ of corn and peas (Sauvant et al., 2003). from faba beans and that this effect increases with greater time and temperature. Thus, roasted to 130 to $150^{\circ} \mathrm{C}$ for 30 to 45 minutes, reduced the starch degradability.

Goelema et al. $(1998,1999)$ studied the effect of roasting on protein and starch degradability faba beans (Vicia faba), finding that a temperature of $132^{\circ} \mathrm{C}$ for 3 minutes decreases protein and starch in situ degradability. The explanation for this is due to the different physic-chemical properties of starches from cereals and legumes. The effect of treatment on the starch also depends on the humidity level. When the heating is done by means of steam, depending on the moisture content, temperature and processing time, the gelatinization could vary, from being just a local to a complete gelatinization, which would increase the starch degradability in the rumen. However, the subsequent cooling and drying, recrystallization may occur. The application of heat and moisture $\left(100^{\circ} \mathrm{C}\right.$ and a humidity of $10-30 \%$ ) for cereals (barley and wheat) and legumes (lentils) did not affect the structure or the physicochemical characteristics of the grains (Offner et al., 2003). However, the starch grains were less compact after treatment. The increase in temperature to $95^{\circ} \mathrm{C}$ increased the starch viscosity from grain, but decreased in legumes starch. These results indicate that the extent of association of starch chain with amorphous region and the crystallization degree were altered during treatment (temperaturehumidity). But the change magnitude was dependent on the starch source and moisture during the heating treatment.

\section{Heat treatment effects on protein degradation}

Usually, the main protein supplements in feed for ruminants are derived from the flour industry, oil or distilleries. In most cases, the products generated by these industries are subjected to thermal or chemical processes, which cause different effects on the quality of the protein and ruminal degradation behavior.

In the case of legume seeds, oilseeds and animal meal, use of heat or solvent treatment, has different consequences. As an improvement in quality due to the elimination or inhibition of antinutritional factors and the improvement of the sanitary quality of the seed or meals. However, heat treatment also causes the desnaturation of proteins by breaking of hydrogen bridges and disulfide linkages responsible for its secondary structure. As a result, reduces its rumen solubility and decreases its degradation rate, increasing the amount of protein without rumen degrading and reaches the intestine intact (Guada, 1993, Van Soest, 1982). Thus, in Figure 4, is observed as the rate of degradation of the soy protein is lower when it is heat-treated soybeans (roasted or extruded). 


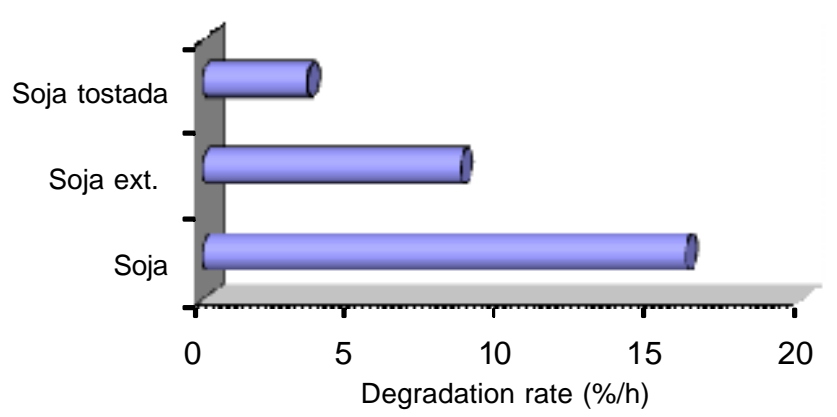

Figure 4 - Effect of extruction or dry roasted of soy bean on degradation rate of crude protein CP (Yu et al., 2002a).

In feed manufacture, use different processes for which it applies an increase in temperature of the material; granulation, extrusion, expander, crushing, the flakes production, steam rolled, etc. Involve the heating of the grain. In addition, during the trial other factors such as moisture level, the amount of carbohydrates soluble present in the material, pressure and the temperature-time treatment to which they are exposed, which will affect the degree of degradability and solubility of proteins.

Exposure to heat, the food cannot only decrease the degradability of protein in the rumen, but also decrease their intestinal digestibility and biological value. So one of the main effects responsible for microbial resistance to proteolysis of heat-treated proteins is the occurrence of Maillard reactions. These are reactions between carbonyl groups of reducing sugars and amino group of lysine. This reaction is reversible in early stages, so if the heat treatment is moderated, you can reduce the ruminal degradability of the protein without affecting its digestibility and available lysine content (Guada, 1993). In addition, other reactions can lead to decreased amino acid availability in the animal, such as condensation reactions (NRC, 1985).

Goelema et al. (1999), studied the effect of different treatments, roasted, granulated and expansion on the protein degradability of legume seeds, noting a decrease. This effect was due to the desnaturation and the formation of Maillard reaction, and was dependent of temperature, processing time and moisture. In Table 2 presents effect of introducing the heat treatment on protein desnaturation and degradation, the effect can go from an increase of hydration and loss of crystalline structure to $50^{\circ} \mathrm{C}$, the loss of secondary structure at $90^{\circ} \mathrm{C}$, until the peptidization and isopeptides formation. Is common the formation of complexes between the cell wall carbohydrates and protein, noting an increase in the crude protein linked with neutral detergent fiber (CP-NDF) and with acid detergent fiber (CP-
$\mathrm{ADF}$ ), these complexes may be similar to the Maillard reaction (Goelema et al., 1999, Yu et al 2002a, AndradeMontemayor, 2005). According to the protein classification Licitra et al. (1996), the B3 protein fraction correspond to the low rumen degradability fraction and can be undegradable fraction, however, not clear whether these fractions can be digested in the intestine or not. One objective of the thermal treatments is reduce the ruminal protein degradability, to avoid losses of nitrogen in the rumen and that this treatment does not affect or alter the digestibility of foods, as well as the decrease in the content and activity of some antinutritional factors, such as lectins and proteases inhibitors, among others, in that sense, AndradeMontemayor (2005) and Pacheco-López and Alegría-Ríos (2008) observed a decrease in ruminal degradability of protein from legume seeds such as Lupins angustifolium, Vicia faba, Vicia Ervilia and Prosopis laevigata, using dry roasting treatment, to a $150^{\circ} \mathrm{C} / 45$ minutes, presenting a greater or lesser effect depending on the legume seed in question, being the variable formation of complexes between $\mathrm{CP}$ and fiber fractions (CP-NDF and CP-ADF). However, in all cases there was no effect in vivo digestibility of the protein. On the other hand, content and activity of antinutritional factors, Pacheco-López and Alegría-Ríos (2008), noted that the roasted pods of mesquite (Prosopis laevigata) had a decrease in the content of proteases inhibitor factors, but an increase in the agglutinating activity of lectins, and in content of condensed tannins, the latter has not been clarified.Furthermore observed an increase in the content of CP-NDF and CP-ADF without affect protein digestibility.

Moreover, the decrease in the protein degradability and modify the carbohydrates degradation, has as its objectives, prevent the loss of nitrogen and energy in the rumen, and increase or improve microbial protein synthesis, so that then define some concepts related to this topic and the factors that are involved in the increase or modification of the synthesis.

Table 2 - Effect of heat on desnaturation and degradation of protein (Yu et al., 2002a)

\begin{tabular}{ll}
\hline Temperature $\left({ }^{\mathrm{o}} \mathrm{C}\right)$ & \multicolumn{1}{c}{ Effect of heating } \\
\hline 50 & Increase hydratation, some loss of crystalline structure \\
$70-80$ & Disulfide splitting, loss of tertiary structure \\
$80-90$ & Loss of secundary structure disulfides \\
$90-100$ & Intermolecular disulfides formed \\
$100-150$ & Lysine and serine loss, isopeptide formation \\
$150-200$ & Peptidization and more isopeptide formation \\
$200-250$ & Pyrolysis of all amino acid residues \\
\hline
\end{tabular}




\section{Microbial protein synthesis}

The theoretical definition of the "microbial protein synthesis (MPS) includes the total amount of protein of microbial origin produced in the rumen, and is expressed in protein grams or N grams per day (Van Soest, 1994). However, in practice it is measured as the amount of microbial protein synthesized in the rumen which flows into the small intestine of ruminants.

Efficiency of microbial protein synthesis (ESPM) is defined as the amount of microbial matter (expressed as dry matter, protein or $\mathrm{N}$ ) per unit of energetic substrate fermented or energy produced (Broudiscou \& Jouany, 1995) and dependent on the availability of energy and protein, and the efficiency with which microorganisms used these (Sniffen \& Robinson, 1987).

For the study of microbial protein synthesis, be treated aspects related to techniques estimation (MPS), factors that affect it, and equations for microbial synthesis predicting, and nutritional value of microbial protein.

\section{Microbial protein synthesis estimation}

Quantifying microbial protein synthesis is the most important aspects in ruminant protein feeding studies (Broderick \& Merchán, 1992). To estimate the amount of microbial protein synthesized in the rumen which flows into the small intestine of the ruminant markers are used, in order to estimate the total microbial marker that leaves the rumen and/or flowing to the small intestine and the concentration of this marker in the microbial mass (Broudiscou and Jouany, 1995).

In in vivotechniques, to estimate the flow of microbial protein, required of animals with duodenal cannulas for the collection of the total digesta, where samples are taken from the duodenal flow and estimated the total flow through use of one or two flow markers.

In addition, the other necessary component to estimate microbial protein synthesis consists in differentiating microbial protein synthesized from other nitrogen compounds flowing into the small intestine, for which markers are used, that supposed to characterize the microbial components (Stern \& Hoover, 1979), and estimated the ratio N/microbial marker (Titgemeyer, 1997).

There are markers for differentiating the microbial protein. The markers themselves may be constituents of microorganisms (internal microbial markers) or chemicals that are incorporated in experimental microbial bodies (external markers). As internal markers exist the DAPA (diaminopimélico acid), aminoethyl-phosphonic acid (AEP), D-alanine, nucleic acids (DNA and RNA) and the puric bases content; and as external markers identified isotopes: $\mathrm{N}^{15}, \mathrm{P}^{35}$ and $\mathrm{S}^{35}$ (Broderick \& Merchen, 1992).

These methods have problems as the complexity of procedures, their cost and the carrying out surgical operations on animals. Existin vitroexperimental procedures, such as continuous or semi-continuous culture systems, which can measure the total synthesis through the effluent collection, while controlling the change of the liquid and solid fractions, without need the use of flow markers (Calsamiglia et al., 1995). Moreover, other methods such as purine derivative (PD) in urine excretion are a very interesting non-invasive technique to predict the flow of microbial protein (Chen et al., 1990a). The method is based on nucleic acids leaving the rumen are of microbial origin, because the food usually used in ruminant feed is low in purines, and the majority of these compounds are degraded by ruminal fermentation. So that the puric bases (PB) of nucleic acids reaching the duodenum are mostly of microbial origin, being absorbed at the intestinal level.

These compounds are metabolized in the animal body excreted derivatives (allantoin, uric acid, xanthine and hypoxanthine) in urine. Thus, the excretion of PD is directly related to the absorption of $\mathrm{PB}$, could establish predictive equations of purines absorbed using the value of PD excreted (Balcells et al., 1991).

Knowing that the relationship between $\mathrm{N}$ and microbial purines absorbed we can estimate intestinal flow of microbial $\mathrm{N}$ or protein. This method requires the use of predictive equations for each species because of differences in purines metabolism, associated with the specific activity of xanthine oxidase among animal species, as well as the plasma concentration, the rate of filtration glomerular and the contribution of endogenous derivatives purics (Chen \& Gomes, 1992, Sandoval-Castro \& Herrera-Gomez, 1999).

Thus, in bovine xanthine oxidase activity in the intestinal mucosa is high but in sheep is low, so the puric derivative excreted profile differed between species. Chen $\&$ Gomes (1992) suggest that in sheep the total purines excreted in urine, have a excretion range of $60-80 \%$ of allantoin, 30-10\% of uric acid and xanthine + hypoxanthine $5-10 \%$, whereas the range for cattle is $80-85 \%$ of allantoin and $20-15 \%$ uric acid, xanthine and hypoxanthine were not detected.

As a result, these factors have been estimated in sheep (Elliott \& Topps, 1965; Fujihara et al., 1987; Chen et al., 1990a, b, c; Chen et al., 1997; Balcells et al., 1991; Chen et al., 1991), cattle (Chen et al., 1990c; Verbic et al., 1990; Giesecke et al., 1984, 1994; Martín-Orúe et al., 2000; Orellana et al., 2001) and buffalo (Liang et al., 1994, IAEA, 1997, 
1998, Chen et al., 1996) derived several equations to determine the synthesis of microbial protein.

In goats, these studies have been conducted primarily in young animals (Lindberg, 1989, Lindberg, 1991; Fujihara et al., 1999; Fujihara et al., 2000) that found patterns of excretion of purine derivatives similar to sheep.

In the urine of both species can be found allantoin, uric acid, hypoxanthine and xanthine, which suggests the existence of a similarity in the puric metabolism between these two species, because the excretion of these puric derivatives is the product of the enzymatic activity characteristic of the both species (Stangassinger et al., 1995).

However, in adult goats of Murciano-Granadino breed (Belenguer et al., 2002; Mota et al., 2003; AndradeMontemayor et al., 2004) has found that the relationship between the puric bases absorption and excretion pattern of PD differs between sheep and goats, finding a greater excretion of hypoxanthine that uric acid in goats. Furthermore, both species had low activity of intestinal xanthine oxidase (Chen et al., 1990b; Chen \& Gomes, 1992; Belenguer et al., 2002). In addition, Mota et al. (2003) noted that the contribution of endogenous and exogenous nucleic acids in the excretion of PD in the goat milk, which is similar to dairy cows. Thus, in recent years are making significant progress in the understanding of digestion and metabolism of purines, as well as the excretion of their derivatives, to minimize errors and adjust the predictive equations in goats. However, they are still insufficient to obtain specific prediction equations of this synthesis in goats, especially knowing that factors such as species, age and possibly race the animal can influence (Andrade-Montemayor et al., 2004).

\section{Factors affecting the synthesis of microbial protein}

Due to the complexity of microbial protein synthesis, there are many factors affecting the performance of the same (Dewhrust et al., 2000). In this line, mentioned the contributions of energy and nitrogen in the rations, as the most limiting factors for microbial protein synthesis in the rumen (Clark et al., 1992), although other nutrients such as sulfur, volatile fatty acids, fatty acids of branched chain, minerals and vitamins, are also very important for microbial growth, although in smaller quantities. In the synthesis of microbial protein there other factors such as ruminal $\mathrm{pH}$ and the rate of renewal of the liquid and solid fractions of rumen content (dilution rate), these factors are related to the complex chemistry and dynamics of ruminal half.

\section{Energy sources}

Carbohydrates are the main source of energy for microbial protein synthesis in the rumen (Sniffen et al., 1983). Other sources, like protein or glycerol and triglycerides, may provide some energy. The main differences in the carbohydrates degree and rate of degradation depending on their type (structural or non structural).

In in vitro studies showed that the non-structural carbohydrates supported the growth of rumen microorganisms. Thus, Demeyer \& Van Nevel (1986), observed an increase in the synthesis and the efficiency of microbial protein synthesis when the quantity of maize was increased replacing the structural carbohydrate such as cellulose.

In in vivo experiments, has found that inclusion of moderate amounts of non-structural carbohydrates in forage-based diets stimulates the synthesis of microbial protein synthesis and its efficiency (Archimede et al., 1997). However, there is also evidence from studiesin vivo, which shows how high levels of non-structural carbohydrates in the diet may adversely affect the microbial protein synthesis and production efficiency (Van Nevel and Demeyer, 1986). This effect appears to be related to the inclusion of high levels of non-structural carbohydrates in the diet, may cause changes in the fermentation pattern by altering microbial growth. Thus, Hagesmeister et al. (1988) studied the influence of the concentrates proportion in diets for ruminants on the synthesis of microbial protein, finding that, low energy input (i.e., high proportion of roughage in the food ration), the protein synthesized per $100 \mathrm{~g}$ of digestible organic matter fermented in the rumen (DOMFR) would be only 15 to $20 \mathrm{~g}$, with high levels of concentrate in the ration resulting in a low $\mathrm{pH}$ can also be expected that the synthesis of microbial protein is only 14-18 g/100g MODFR. While gets the highest synthesis of microbial protein with intermediate levels of carbohydrates, which do not alter the ruminal physiology.

As a result, depending on the type and level of carbohydrate, the synthesis of microbial protein is affected, because the profile of release of energy for microbial growth and the conditions of the ruminal environment can be modified.

\section{Source of protein}

Ruminal microorganisms used for the synthesis of microbial protein, different sources of nitrogen resulting from the degradation of protein fractions of the ration, such as ammonia, amino acids and peptides, or urea recycled. As a result, besides of energy, other factors limiting the synthesis of microbial protein like nitrogen contribution (Stern et al., 1994a, b). Thus, protein synthesis has increased 
by increasing the content of degradable protein in the diet (Erasmus et al., 1994). This is because in protein degradation the end product is ammonia, which is considered the main source of $\mathrm{N}$ for microbial protein synthesis in the rumen (Mackie \& White, 1990). However, an excess of protein degradable protein can cause an accumulation of ammonia in the rumen and nitrogen loss. So that there are some studies conducted by Calsamiglia et al. (1995), which show that there are no differences in the synthesis, or efficiency of microbial protein synthesis, when using multiple sources of different protein degradability, and if the rations contain less than $9 \%$ degradable protein, limit microbial growth. As a result, there should be an optimal concentration of ammonia in the rumen to maximize yields.

Thus, there is controversy over the minimum concentration of ammonia to maximize the efficiency of microbial protein synthesis. Satter \& Slyter (1974) suggest an optimal value for the growth of microorganism $5 \mathrm{mg} \mathrm{N}$ $\mathrm{NH}_{3} / 100 \mathrm{~mL}$ in the rumen. Although this optimal concentration, appears to be higher, when administered easily fermentable substrates (Broudiscou and Jouany, 1995). However, there is great variability of results, depending on many factors related to the constituents of the rations, food handling and experimental conditions, implying that bacterial growth depends on many other factors besides the concentration $\mathrm{N}$ ammonia. For microbial growth, are also necessary other nitrogen sources, like amino acids and peptides, as these can be incorporated directly into microbial protein of certain bacterial groups, such as amylolytic bacteria (Wallace, 1988, Russell et al., 1992;) . Other authors, such as Oldham (1988) suggest that the amino acids of the food can be used directly, which $s$

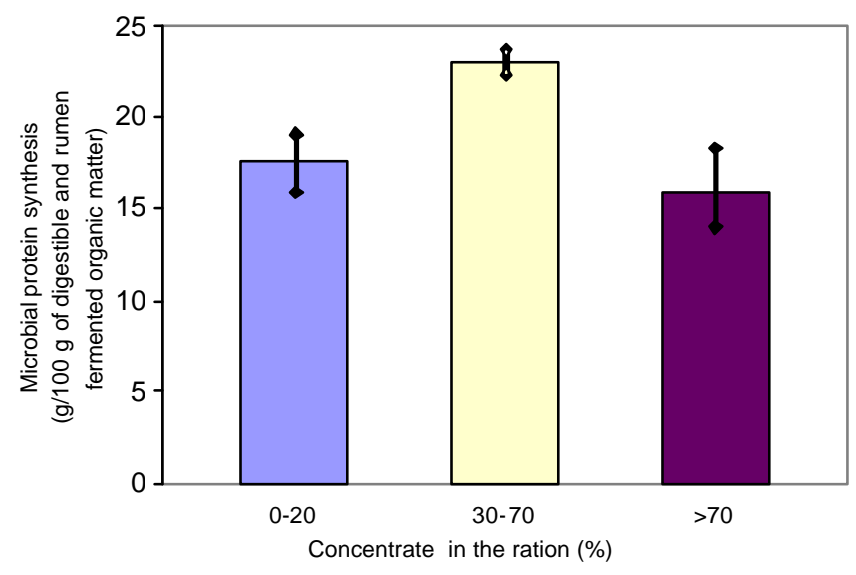

Figure 5 - Influence of concentrate (\%) on microbial protein synthesis in rumen (Hagesmeister et al., 1988). analyze the contribution of $\mathrm{N}$ of urea or $\mathrm{N}$ of amino acid on microbial nitrogen production in absolute terms and in terms of energy efficiency, and have a positive effect on microbial growth when the substrate contains amino acids preformed N (Figure 6).

\section{Synchronization of energy and protein}

Synchronized input of $\mathrm{N}$ degradable and carbohydrates fermentable results in better utilization of nutrients in the rumen and a greater flow of microbial protein to the duodenum (Dewhrust et al., 2000), because the microorganism supply of nutrients in proportion and appropriate time. Thus, Newbold \& Rust (1992) conducted anin vitro experiment in which the supplemented ruminal medium with urea and glucose, simultaneously, supplying $25 \mathrm{mg} \mathrm{N} / \mathrm{g}$ of glucose per hour, or varying the flow of 0.13 to $48.9 \mathrm{mg} \mathrm{N} / \mathrm{g}$ glucose over time, adjusting the administration of glucose and urea by the end of both treatments, the quantity supplied of these elements were the same. As a result of this experiment showed that the microbial population was higher in the medium in which administered glucose and urea in a synchronized form (Figure 7).

\section{Time in hours}

A classic example used to demonstrate the negative effect of asynchrony is when we study the synthesis of microbial protein in silage-based rations. During the silage material undergoes microbial fermentation, so the nonstructural carbohydrates ferment and part of the protein is degraded to ammonia. As a result when you bring these foods to the animals, the rumen microorganisms have a high rate of ammonia but not few fermented carbohydrates that

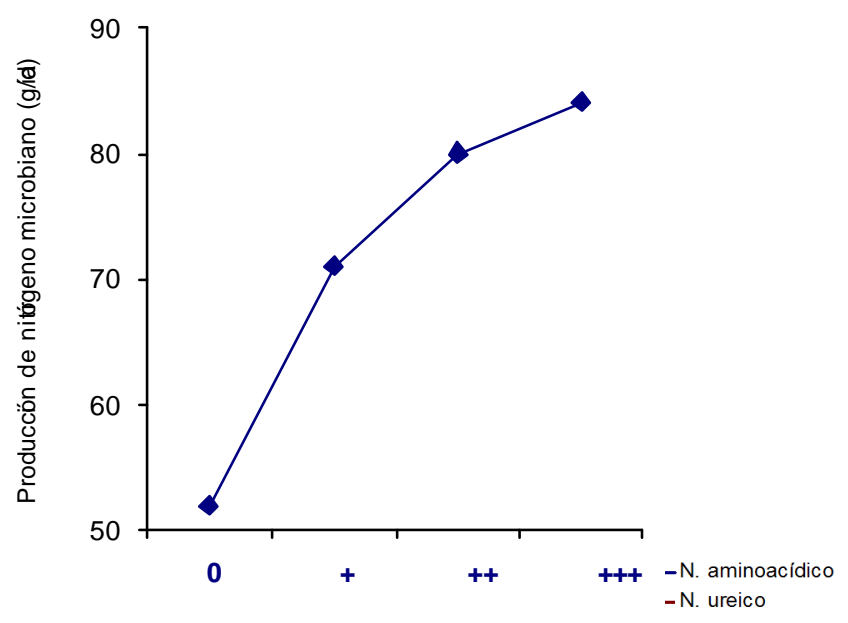

Figure 6 - Effect of $\mathrm{N}$ input from amino acid and/or urea on the production of microbial $\mathrm{N}(\mathrm{g} / \mathrm{d})$ ) (adapted from Oldham, 1988). 


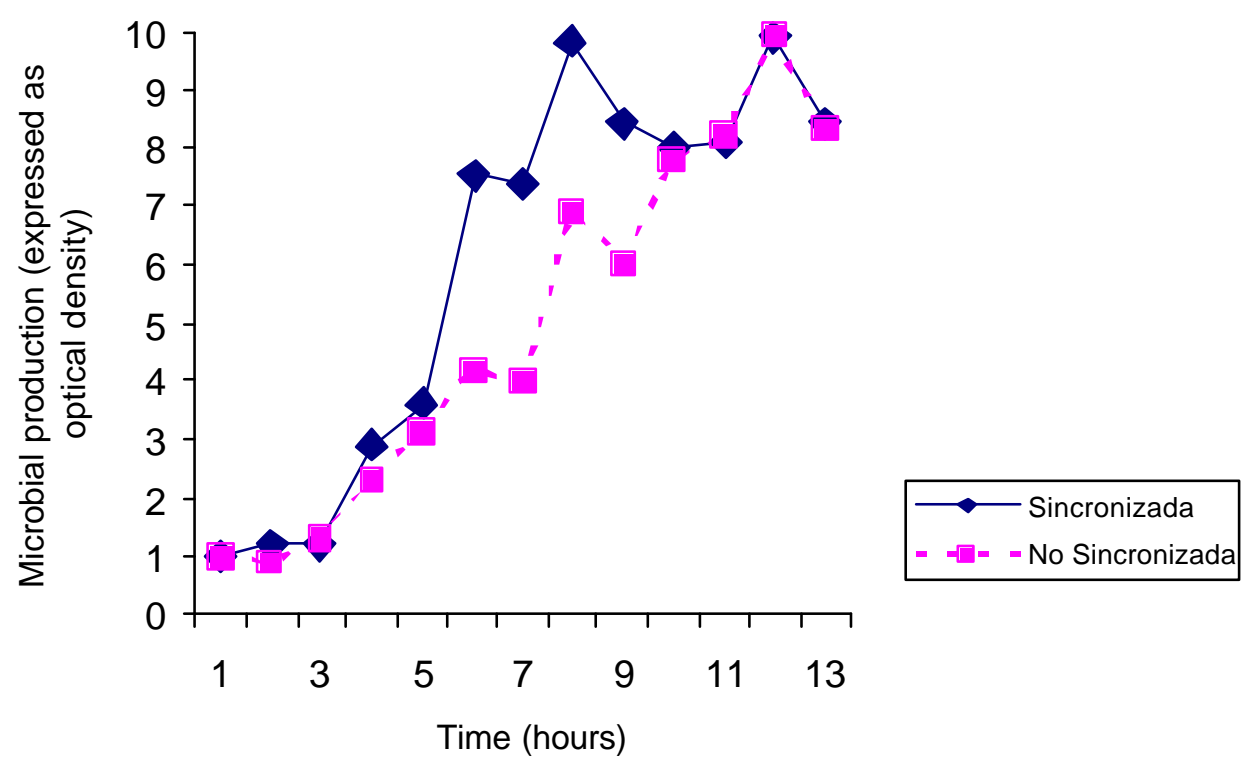

Figure 7 - Effect of the sincronization of urea and glucose administration on microbial protein production in ruminal medium invitro (adapted of Newbold \& Rust, 1992).

are a source of energy for their growth, and decreasing the synthesis of microbial protein (Rooke et al., 1987).

To stimulate the synthesis of microbial protein, the pattern of nutrient release must occur in synchrony, with the use of recommended sources of protein and carbohydrates readily degradable (Herrera-Saldana et al., 1990). However, although the increases in the ration of carbohydrate and protein degradable sources leads to an increase in microbial protein synthesis, it should be noted that some studies show as rations with increasing levels of non-structural carbohydrates may decrease microbial protein synthesis (Feng et al., 1993). This effect is related to high amounts of non-structural carbohydrates, as these can cause changes in the ruminal environment $(\mathrm{pH}$ and dilution rate), causing alterations in the microbial growth and efficiency. On the other hand, improve the degree of synchronization in the rate of release of energy and nitrogen in the rumen does not always translate into increased microbial mass (Henning et al., 1993), it is also important that inputs of energy, and $\mathrm{N}$, are produced in a gradual and steady. In addition, other factors related to the animal, provided the source of $\mathrm{N}$ (e.g. simultaneous contribution of ammonia, amino acids and peptides) or changes in the ruminal environment ( $\mathrm{pH}$, dilution rate) can affect the timing of nutrient microbial protein synthesis.

\section{Other factors related to nutrient availability}

There are many nutrients in addition to carbohydrate and nitrogen sources, which are supplied in the diet and have a significant effect on the microbial protein synthesis and the efficiency. Among these nutrients can be fats, branched volatile fatty acids, minerals, vitamins, etc.

Fat is not efficient energy source for the rumen microbial growth (Dewhrust et al., 2000), their addition in moderate proportions can improve the efficiency of synthesis (Klusmeyer et al., 1991), as fat addition appears to reduce the number of protozoa, which decreases the predation of bacteria in the rumen. However, when fat intake in the diet is high (e.g.> $8 \%$ of the ration DM), can occur negative effects, as reduction in fiber digestion due to a toxic effect cellulolytic microorganism, adversely affecting the efficiency of microbial protein synthesis (Oldick \& Firkins, 2000).

Furthermore, branched volatile fatty acids are important for the growth of cellulolytic bacterias (Hoover, 1986), recommending an additional contribution of the same if the presence of protein degradable in the diet is low. There are other nutrients such as minerals, such as S (necessary for methionine and cysteine microbial synthesis), $\mathrm{P}$ (for the formation of microbial nucleic acids) or $\mathrm{Mg}$ (needed for the activity of many microbial enzymes), to be made in quantities that will not limit microbial growth (Van Soest, 1994).

Other components that may affect the microbial synthesis

Thus, the inclusion of ionophore antibiotics in the diet of ruminants, such as monensin, reduces the degradation of the protein in the rumen (Yang \&d Russell, 1993), but clearly do not know its effects on the production of microbial protein. Currently, other ingredients are also identified as factors that may influence microbial fermentations and, 
therefore, the synthesis and efficiency of microbial protein synthesis. Among these ingredients include probiotics, such as yeasts and fungi that can improve the ruminal environment, and using active oxygen stabilizing the $\mathrm{pH}$, stimulating microbial growth especially cellulolytic bacteria (Williams et al., 1991). Also the inclusion of various organic acids such as malate, and plant extracts are being studied in relation to their effects on rumen microbial activity (Caja et al., 2003).

\section{Conclusions}

The regional legume seeds may be alternative protein and carbohydrate sources, in the goats feeding. However, its protein is highly degradable, which may cause loss of nitrogen and/or energy in the rumen, also presented several antinutritional factors that may affect the digestibility and utilization of various nutrients, among these factors are trypsin inhibitors, lectins, hemoaglutinantes, alkaloids and tannins. There are several technological treatments, which can alter the protein and carbohydrates degradability, and cause a decrease in the content and activity of some antinutritional factors, among these treatments, the dryroasted, has proved its effectiveness in reducing the degradability protein modification and degradation of carbohydrates, as well as the modify the content and activity of some antinutritional factors. Knowledge, of the shape and the effect of these treatments in changing the behavior of the various nutrients may help to manipulate the microbial protein synthesis, dependent on inputs of nitrogen and carbohydrates, and synchronization in the degradation of these, as well as increasing the passage of food protein into the intestine.

\section{Literature Cited}

ANDERSON, L.P.; PATERSON, R.P.; CECAVA, M. et al. The effects of degradable and undegradable intake protein on the performance of lactating first-calf heifers. Journal of Animal Science, v.79, p.2224-2232, 2001.

ANDRADE-MONTEMAYOR, H.; HERNÁNDEZ, F.; MADRID, J.; MEGÍAS, M.D. Comparison of different models to estimate purine bases absorbed in goats. South Africa Journal of Animal Science, v.34, p.28-30, 2004 (suppl. 1).

ANDRADE-MONTEMAYOR, H. Valoración nutritivo de dos sistemas de alimentación y evaluación del uso de fuentes alternativas de proteína vegetal en la alimentación de caprinos. 2005. 450f. Tesis Doctoral Dep. Producción Animal Facultad de Veterinaria-Universidad de Murcia. España. 2005.

ANNISON, E. F.; LEWIS, D. M. A. EI metabolismo del rumen 1.ed. en español. S. A. de C.V. México: Editorial HispanoAmericano, 1981.

ARCHIMÈDE, H.; SAUVANT , D.; SCHMIDELY, P. Quantitative review of ruminal and total tract digestion of mixed diet organic matter and carbohydrates. Reproduction Nutrition
Development, v.37, p.173-189, 1997.

BACH, A.; CALSAMIGLIA, S. Manual de racionamiento para el vacuno lechero. 1.ed. España: Servet Editores, 2002.

BALCELLS, J.; GUADA, J.A; CASTRILLO, C. et al. Urinary excretion of allantoin precursors by sheep alter different rates of purine infusion into the duodenum. Journal of Agricultural Science Cambrigde, v.116, p.309-317, 1991.

BALCELLS, J.; FONDEVILLA, M.; GUADA, J.S. et al. Urinary excretions of purine derivatives and nitrogen in sheep given straw supplemented with different sources of carbohydrates. Animal Production, v.57, n.287-292, 1993.

BALDWIN, R. L.; ALLISON, M. J. Rumen metabolism. Journal of Animal Science, v.57, p.461-475, 1983 (suppl. 2).

BELENGUER, A.; YÁÑEZ, D.; BALCELLS, D.J. et al. Urinary excretion of purine derivatives and prediction of rumen microbial outflow in goats. Livestock Production Science Journal, v.77, p.127-135, 2002.

BHATTA, R.; VAITHIYANATHAN, S.; SINGH, N.P. et al. Effect of feeding complete diets containing graded levels of Prosopis cineraria leaves on feed intake, nutrient utilization and rumen fermentation in lambs and kids. Small Ruminant Research, v.67, p.75-83, 2007.

BLAS, C. de; REBOLLAR, P.G.; MÉNDEZ, J. Utilización de cereales en dietas de vacuno lechero. In: REBOLLAR, P.G.A.; MATEOS, G.G.; DE BLAS, C. (Eds.). Avances en nutrición y alimentación animal. Fira de Barcelona, España: Fundación Española para el Desarrollo de la Nutrición Animal, 1995. p.48-67.

BRENES, A.; BRENES, J. Tratamiento tecnológico de lo granos de leguminosas: influencia sobre su valor nutritivo. IX Curso de especialización FEDNA. Barcelona, España. 1993.

BRODERICK, G.A.; MERCHEN, N.R. Markers for quantitying microbial protein synthesis in the rumen. Journal of Dairy Science, v.75, p.2618-2632, 1992.

BRODERICK, G.A. Quantifying forage protein quality. In: FAHEY JR., G.C. (Ed.). Forage quality evaluation and utilization. Madison: American Society of Agronomy, 1994. p.200-229.

BROUDISCOU, L.; JOUANY, J.P. Reassessing the manipulation of protein synthesis by rumen microbes. Reproduction Nutrition Development, v. 35, p.517-535, 1995.

CAJA, G.; GONZÁLEZ, E.; FLORES, C. et al. Alternativas a los antibióticos de uso alimentario en rumiantes: probióticos, enzimas y ácidos orgánicos. In: REBOLLAR, P.G.A.; DE BLAS, C.; MATEOS, G.G. (Eds.). Avances en nutrición y alimentación animal. Fira de Barcelona, España: Fundación Española para el Desarrollo de la Nutrición Animal, 2003. p.193214.

CALSAMIGLIA, S.; STERN, M. D.; FIRKINS, J. L. Effects of protein source on nitrogen metabolism in continuous culture and intestinal digestion in vitro. Journal of Animal Science, p.73, v.1819-1827, 1995.

CASTRILlo, C.; BALCELls, J. Aspectos básicos del metabolismo ruminal del nitrógeno. Pequeños Rumiantes. Ed. SEOC. 2002. p.14-26.

CHEN, B.X.; HOVELL, F.D.B.; ØRSKOV, E.R. Excretion of purine derivatives by ruminants: recycling of allantoin into the rumen by saliva and its fate in the gut. British Journal Nutrition, v.63, p.197-205, 1990a.

CHEN, B.X.; HOVELL, F.D.B.; ØRSKOV, E.R. et al. Excretion of purine derivatives by ruminants: effect of exogenous nucleic acid supply on purine derivative excretion by sheep. British Journal Nutrition, p.63, v.131-142, 1990b.

CHEN, B.X.; ØRSKOV, E.R.; HOEVELL, F.D.B. Excretion of purine derivatives by ruminants: endogenous excretion, differences between cattle and sheep. British Journal Nutrition, p.63, v.121-129, 1990c.

CHEN, B.X.; KYLE, D.J.; ØRSKOV, E.R. et al. Renal clearance of plasma allantoin in sheep. Experimental Physiology, v.76, p.59-65, 1991.

CHEN, B.X.; GOMES. J.M. Estimation of microbial protein 
supply to sheep and cattle based on urinary excretion of purine derivatives - An overview of the technical details. Bucksburn: Rowett Research Institute, International Feed Resources Unit, 1992 (Occasional Publication).

CHEN, B.X.; CHEN, Y.K.; FRANKLIN, M.F. et al. The effect of feed intake and body weight on purine derivative excretion and microbial protein supply in sheep. Journal of Animal Science, v.70, p.1534-1542, 1992 .

CHEN, B.X.; MEJIA, A.T.; KYLE, D.J.; ØRSKOV, E. R. Evaluation of the use of purine derivative: creatinine ratio in spot urine and plasma samples as an index of microbial protein supply in ruminants: studies in sheep. Journal of Agricultural Science Cambrigde, v.125, p.137-143, 1995.

CHEN, B.X.; SAMARAWEERA, L.; KYLE, D. J. et al. Urina excretion of purine derivatives and tissue xanthine oxidase (EC 1.2.3.2) activity in buffaloes (Bubalis bubalis) with special reference to differences between buffaloes and Bos taurus cattle. British Journal Nutrition, v.75, n.3, p.397-407, 1996.

CHEN, B.X.; FUJIHARA, T.; NAKAMURA, K. et al. Response of urinary and plasma purine derivatives to various rates and infusion patterns of purines in sheep nourished by intragastric infusion. Journal of Agricultural Science, v.129, p.343352, 1997.

CHEN, X.B.; ØRSKOV, E.R. Research on urinary excretion of purine derivatives in ruminants: past, present and future. Internal report. International Feed Resource Unit. Macaulay Land Use Research Institute. Aberdeen. UK. 2004 . p.1-34. Disponible en la URL: http://www. mluri.sari.ac.uk/ifru/pdf/ pd_review.pdf (Consultado 21/Enero/2009).

CHESSON, A.; FORSBERG C.W. Polysaccharide degradation by rumen microorganisms. In: HEBSON, P.N. (Ed.). The rumen microbial ecosystem. London: Elsevier Applied Science, 1988. p.251-284.

CLARK, J.H.; KLUSMEYER, T.H.; CAMERON, M. R. Microbial protein synthesis and flow of $\mathrm{N}$ fraction to the duodenum from the rumen. Animal Feed Science and Technology, v.85, p.121,1992 .

DEMEYER, D.L.; Van NEVEL C.J. Influence of substrate and microbial interaction on efficiency of rumen microbial growth. Reproduction Nutrition Development, v.26, p.161-179, 1986.

DEWHURST, R.J.; DAVIES, D.R.; MERRY, R. Microbial protein supply from the rumen. Animal Feed Science and Technology, v.85, p.1-21, 2000.

DIJKSTRA, J.; FRANCE, J.; DAVIES, D. Different mathematical approaches to estimating microbial protein supply in ruminants. Journal of Dairy Science, v.81, p.3370-3384, 1998.

El FIEL, H.E.A.; EL TINAY, A.H.; ELSHEIKH, E.A.E. Effect of nutritional status of faba bean (Vicia faba) on protein solubility profiles. Food Chemistry, v.76, p.219-223, 2002.

TOPPS. Relationship between concentrations of ruminal nucleic acids and excretion of purine derivatives by sheep. Nature, v. 205, p.498-499, 1965 .

ERASMUS, L.J.; BOTHA, P.M.; MEISSENER, H.M. Effect of protein source on ruminal fermentation and passage of amino acids to the small intestine of lactating cows. Journal of Dairy Science, v.77, p.3655-3665, 1994.

FENG, P.; HOOVER, W.H.; MILLER, T.K. et al. Interactions of fiber and nonstructural carbohydrates on lactation and ruminal function. Journal of Dairy Science, v.76, p.1324-1333, 1993.

FUJIHARA, T.; ØRSKOV, E.R.; REEDS, P.J. et al. The effect of protein infusion on urinary excretion of purine derivatives in ruminants nourished by intragastric nutrition. Journal of Agricultural Science, v.109, p.7-12, 1987.

FUJIHARA, T.; IWAKUNI, M.; MIYATA, Y.K. The effect of rumen protozoa on plasma allantoin level and urinary excretion of purine derivatives in sheep. South Africa Journal of Animal Science, v.29, p.137-138, 1999

FUJIHARA, T.; MIYATA, K.; HIRANO, T. Effects of fasting and purine-free diet on urinary excretion and blood plasma levels of allantoin in growing goats. In: INTERNATIONAL CONFERENCE ON GOATS, 7., 2000, Tours. Proceedings... Tours: International Goat Association (IGA), 2000. p.83

GIESECKE, D.; STANGASSINGER, M.; TIEMEYER, W. Nucleic acid digestion and urinary purine metabolites in sheep nourshed by intragastric infusion. Canadian Journal of Animal Science, v.64, p.144-145, 1984 (suppl. 1).

GIESECKE, D.; EHRENTREICH, L.; STANGASSINGER, M. et al. Mammary and renal excretion of purine metabolites in relation to energy intake and milk yield in dairy cows. Journal of Dairy Science, v.77, p.2376-2381, 1994.

GOELEMA, J.O.; SPREEUWENBERG, M.A.M.; HOF, G. et al. Effect of pressure toasting on the rumen degradability and intestinal digestibility of whole and broken peas, lupin and faba beans and mixture of these feedstuffs. Animal Feed Science and Technology, v.76, p.35-50, 1998.

GOELEMA, J.O.; SMITS, A.; VAESSEN, L.M. et al. Effects of pressure toasting, expander treatment and pelleting on in vitro and in situ parameters of protein and starch in a mixture of broken peas, lupins and faba beans. Animal Feed Science and Technology, v.78, p.109-126, 1999.

GONZÁLEZ, J.S.; CARRO, M.D.; LÓPEZ, S. Digestión ruminal de los forrajes. In: BERMUDEZ, F.F. (Ed.). Nutrición de rumiantes en zonas áridas y de montaña. Madrid: CSIC, 1991. p.93-104.

GUADA, J.A. Efectos del procesado sobre la degradabilidad ruminal de proteína y almidón. IX Curso de especialización FEDNA. Barcelona. España. 1993

HA, J.K.; KENNELLY, J.J. In situ dry matter and protein degradation of various protein sources in dairy cattle. Canadian Journal of Animal Science, v.64, p.443-452, 1984.

HAGESMEISTER, H.; LÜPPING, W.; KAUFMANN, W. Síntesis de proteína microbiana y digestion en las vacas lecheras de alta producción. In: HARESINGN, W.; COLE, D.J.A. (Eds.). Avances en nutrición de los rumiantes. Zaragoza: Acribia, 1988. p.35-51.

HENNING, P.H.; STEYN, D.G.; MEISSNER, H.H. Effect of synchronization of energy and nitrogen supply on ruminal characteristics and microbial growth. Journal of Animal Science. v.71, p.2516-2528, 1993.

HERRERA-SALDANA, R.; GÓMEZ-ALARCÓN, R.; TORABI, M. et al. Influence of synchronizing protein and starch degradation in the rumen on nutrient utilization and microbial protein synthesis. Journal of Animal Science v.73, p.142-143, 1990.

HOOVER, E.H.; MILLER, T.K. Rumen digestive physiology and microbial ecology. In: Bulletin $708 \mathrm{~T}$ of Agricultural and Forestry Experimental Station. West Virginia University, USA. 1992. p.36.

HOOVER, W.H.; STOKES, S.R. Balancing carbohydrates and proteins for optimum rumen microbial yield. Journal of Animal Science, v.74, p.3630, 1991 .

HUNTINGTON, G. Starch utilization by ruminant: from basics to the bunk. Journal of Animal Science, v.75, p.852-867, 1997.

IAEA (International atomic energy agency). Estimation of rumen microbial protein production from purine derivatives in urine. A laboratory manual for the FAO/IAEA Co-ordinated research programme on development, standarization and validation of nuclear based technologies for measuring microbial protein supply in ruminant livestock for improving productivity. Vienna, Austria. 1997.

INRA. Alimentation des bovines, ovins \& caprins. Paris: INRA, 1988. p.476-480.

KLUSMEYER, T.H.; LYNCH, G.L.; CLARK, J.H. et al. Effects of calcium salts of fatty acids and protein source on ruminal fermentation and nutrient flow to duodenum of cows. Journal of Dairy Science, v.74, p.2206-2219, 1991

KOTARSKI, F.S.; WANISKA, R.D.; THURN, K.K. Starch hydrolysis by the ruminal microflora. Journal of Nutrition, v.122, p.178$190,1992$. 
KREUZER, M. Grain legumes in ruminant nutrition: feeding value and potential effects on harmful trace gas emissions. In: Grain legumes and the environment: how to assess benefits and impacts? Zurich (Switzerland), 2004. p.20.

LIANG, B.J.; MATSUMOTO, M.; YOUNG, B.A. Purine derivative excretion and ruminal microbial yield in Malaysian cattle and swamp buffalo. British Journal Nutrition, v.47, p.189-199, 1994.

LINDBERG, J.E. Nitrogen metabolism and urinary excretion of purines in goat kids. British Journal Nutrition, v.61, p.309$321,1989$.

LINDBERG, J. E. Nitrogen and purine metabolism in preruminant and ruminant goat kids increasing amounts of ribonucleic acids. Animal Feed Science and Technology v.35, p.213-226, 1991.

LYKOS, T.; VARGA, G.A. Effects of processing method on degradation characteristics of protein and carbohydrate source In situ. Journal of Dairy Science, v.78, p.1789-1801, 1995.

MACKIE, R.I.; WHITE, B.A. Recent advances in rumen microbial ecology and metabolism: Potential impact on nutrient output. Journal of Dairy Science, v.73, p.2971-2995, 1990.

MAHADEVAN, S.; ERFLE, J. .; SABER, F.D. Degradation of soluble and insoluble proteins by Bacteroides amylophilus protease and by rumen microorganisms. Journal of Animal Science, v.50, p.723-733, 1980 .

MAKKAR, H.P.S. Effect and fate of tannins in ruminant animals, adaptation to tannins, and strategies to overcome detrimental effects of feeding tannin-rich feeds. Small Ruminant Research, v.49, p.241-256, 2003.

MARTÍN-ORÚE. S.M.; BALCELLS, J.; GUADA J.A. et al. Microbial nitrogen production in growing heifers: direct measurement of duodenal flow of purine bases versus urinary excretion of purine derivatives as estimation procedures. Animal Feed Science and Technology, v.88, p.171-188, 2000.

McDONALD, I. A revised model for estimation of protein degradability in the rumen. Journal of Agricultural Science Cambrigde, v.96, p251-252, 1981.

McDONALD, P.; EDWARDS, R.A.; GREENHALGH, J.F.D. et al Animal nutrition. 5.ed. London: Addison Wesley Longman Limited, 1995.

MOTA M.; BALCELLS, J.; OZDEMIR BABER, N.H. et al. Endogenous contribution and effect of exogenous nucleic acid supply on urinary excretion of purine derivatives in dairy granadina goats. In: JOINT SEMINAR OF THE FAO-CIHEAM SHEEP AND GOAT NUTRITION AND MOUNTAIN AND MEDITERRANEAN PASTURE SUB-NETWORKS. "Sustainable grazing, nutritional utilization and quality of sheep and goat products", 1., 2003, Granada. Proceedings... Granada: 2003. p.93

NEWBOLD, J.R.; RUST, S.R. Effect of asynchronous nitrogen and energy supply on growth of ruminal bacterias in batch culture. Journal of Animal Science, v.70, p.538-546, 1992.

NOCEK, J.; TAMMINGA. S. Site of digestion of starch in the gastrointestinal tract of dairy cows and its effect on milk yield and composition. Journal of Dairy Science, v.74, p.35983629, 1991

NATIONAL RESEARCH COUNCIL - NRC. Ruminant nitrogen usage. Subcommittee on nitrogen usage in ruminants. Edit: Washington, D.C.: National Academic Press, 1985.

NATIONAL RESEARCH COUNCIL - NRC. Nutrient Requirements of dairy cattle. 6.rev.ed. Washington, D.C.: National Academic Press, 1989.

NATIONAL RESEARCH COUNCIL - NRC. Nutrient requirements of dairy cattle. 7.rev.ed. Washington, D.C.: National Academic Press, 2001

OFFNER, A.; BACH, A.; SAUVANT, D. Quantitative review of in situ starch degradation in the rumen. Animal Feed Science Technology, v.106, p.81-93, 2003.

OLDHAM, J.D. Necesidades en aminoácidos para la lactación en vacas lecheras de alta producción. In: HARESINGN, W.; COLE, D.J.A. (Eds.). Avances en la nutrición de los rumiantes. Zaragoza: Acribia, 1988. p.53-87.

OLDICK, B.S.; FIRKINS, J.L. Effects of degree of fat saturation on fiber digestion and microbial protein synthesis when diets are fed twelve times daily. Journal of Animal Science, v.78, p.2412-2420, 2000.

ORELLANA, P.; MENDOZA, N.; SCORI, M. Relaciones entre la excreción urinaria de derivados de purinas y creatinina con el consumo. Archivos de Medicina Veterinaria, v.30, v.1, p.114, 1998.

ORELLANA, B.P.; BALCELLS, J.; MARTÍN-ORÚE, S.M. et al. Excretion of purine derivatives in cows: endogenous contribution and recovery of exogenous purine bases. Livestock Production Science, v.68, p.243-250, 2001.

ØRSKOV, E.R.; MILLER, E.L. Protein evaluation in ruminants. In: ØRSKOV, E.R. (Ed.) Feed Science. Netherlands: Elsevier Science Publishers B.V., 1988. p.103-127.

ØRSKOV, E. R. Nutrición proteica de los rumiantes. 1.ed. en español. Zaragoza: Acribia, 1988.

OWENS, F. N., GOESTCH, A. L. Digesta passage and microbial protein synthesis. In: INTERNATIONAL SYMPOSIUM ON RUMINANT PHYSIOLOGY, 6., 1984, New Jersey. Proceedings... New Jersey: Reston Book, 1984. p.196-226.

PACHECO-LÓPEZ, M.J, ALEGRÍA RIOS, F.S. Efecto del tostado de vaina de Mezquite (Prosopis laevigata) en la digestibilidad in vivo de materia seca, proteína cruda, fibra detergente neutro y fibra detergente ácido, así como en el balance de nitrógeno. 2008. 78f. Pruebas en Caprinos. Licenciatura en Medicina Veterinaria y Zootecnia. Facultad de Ciencias Naturales, Universidad Autónoma de Querétaro. México. Tesis de Licenciatura. 2008.

ROOKE, J.A.; LEE, N.H.; AMSTRONG, D.G. The effects of intraruminal infusions of urea, casein, glucose syrup and a mixture of casein and glucose syrup on nitrogen digestion in the rumen of cattle receiving grass-silage diets. British Journal of Nutrition, v.57, p.89-98, 1987.

ROONEY, L. W.; PFLUGFELDER, R. L. Factors affecting starch digestibility with special emphasis on sorghum and corn. Journal of Animal Science, v.63, n.1607-1623, 1986.

RUSSEL, J.B.; O'CONNER., J.D.; FOX, D.G. et al. A net carbohydrate and protein system for evaluating cattle diets: I. Ruminal fermentation. Journal of Animal Science, v.70, p.3551-3561, 1992.

SAGARPA [2006]. Secretaría de agricultura, ganadería, desarrollo rural y pesca. Disponível em: <http://www.sagarpa.gob.mx.> Acesso em: 5/1/2009.

SANDOVAL-CASTRO, C.; HERRERA-GÓMEZ, F. Estimación de la síntesis de proteína microbial en rumiantes a través de la medición de los derivados de purina en orina. Revista Biomedica, v.10, p.241-251, 1999.

SATTER, L.D.; SLYTER, L.L. Effect of ammonia concentration on rumen microbial protein production in vitro. British Journal of Nutrition, v.32, p.199-208, 1974.

SAUVANT, D. ; CHAPOUTOT ,P.; ARCHIMEDE, H. La digestion des amidons par les ruminants et ses conséquences. Productions Animales, v.7, p.115-124, 1994.

SAUVANT, D.; MESCHY, F.; MERTENS, D. Les composantes de l'acidose ruminale et les effets acidogènes de rations. INRA. Productions Animales, v.12, n.1, p.49-60, 1999.

SAUVANT, D.; PEREZ, J-M.; TRAN, G. Tablas de composición y de valor nutritivo de las materias primas destinadas a los animales de interés ganadero cerdos, aves, bovinos, ovinos, caprinos, conejos, caballos y peces. 1.ed. en español. Madrid: Ediciones Mundi-Prensa, 2003.

SNIFFEN, C.J.; RUSSELL, J.B.; Van SOEST, P.J. The influence of carbon source, nitrogen source and growth factors on rumen microbial growth factor in rumen microbial growth. In: CORNELL NUTRITIONAL CONFERENCE, 1983, Ithaca. 
Proceedings... Ithaca: 1983. p.26-33.

SNIFFEN, C.J.; ROBINSON, R.H. Microbial growth and flow as influenced by dietary manipulations. Journal of Dairy Science, v.70, p.425-441, 1987.

SNIFFEN, C.J.; O'CONNOR, J.D.; Van SOEST P.J. et al. A net carbohydrate and protein system for evaluating diets: II. Carbohydrate and protein availability. Journal of Animal Science, v.70, p.3562-3577, 1992.

STANGASSINGER, M.; CHEN, X.B.; LINDBERG, J.E. et al. Metabolism of purines in relation to microbial production. In: INTERNATIONAL SYMPOSIUM ON RUMINANT PHYSIOLOGY, 8., 1995. Proceedings... 1995. p. 387-400,

STERN, M.D.; HOOVER, W.H. Methods for determining and factors affecting rumen microbial protein synthesis: a review. Journal of Animal Science, v.49, p.1590-1603, 1979.

STERN, M.D.; SATTER, L.D. Evaluation of nitrogen solubility and the dacron bag technique as methods for estimating protein degradation in the rumen. Journal of Animal Science, v. 58 , p.714-724, 1984

STERN, M.D.; CALSAMIGLIA, S.; ENDRES, M.I. Dinámica del metabolismo de los hidratos de carbono y el nitrógeno en el rumen. X Curso de Especialización FEDNA. Madrid. España. 1994a.

STERN, M.D.; VARGA, G.A.; CLARK, J.H.; FIRKINS, J.L.; Huber, J.T.; Palmquist, D.L. Evaluation of chemical an physical properties of feeds that affect protein metabolism in the rumen. In symposium: metabolic relationship in supply of nutrients for milk protein synthesis. Journal of Dairy Science, v.77, p.2762-2786, 1994b.

STERN, M.D.; BACH, A.; CALSAMIGLIA, S. Alternative techniques for measuring nutrient digestion in ruminants. Journal of Animal Science, v.75, p.2256-2276, 1997.

TAMMINGA, S.; Van STRAALEN, W.M.; SUBNEL, A.P.J. et al. The Dutch protein evaluation system; the DVE/OEB systems. Livestock Production Science, v.40, p.139-155, 1994.

THEURER, C.B.; HUBER, J.T; DELGADO-ELORDUY, A. et al. Invited review: summary if steam-flaking corn or sorghum grain for lactating dairy cows. Journal of Dairy Science, v.82, p.1950-1959, 1999.

TITGEMEYER, E.C. Design and interpretation of nutrient digestion studies. Journal of Animal Science, v.75, p.22352247, 1997.

Van SOEST, J.P. Nutritional ecology of the ruminant. 1.ed. Ithaca: Cornell University Press, 1982.

Van SOEST, J.P. Interaction of feeding behaviour and forage composition. In: International Conference on Goats, 4., 1987, Brasília. Proceedings... Brasília: 1987. p.971-989.

Van SOEST, J. P.; ROBERTSON, J. B.; LEWIS, B.A. Methods for dietary fiber, neutral detergent fiber, and nonstarch polysaccharides in relation to animal nutrition. Journal of Dairy Science, v.74, p.3583-3597, 1991.

Van SOEST, J.P. Nutritional ecology of the ruminant. 2.ed. Ithaca: Cornell University Press, 1994.

VERBIC, J.; CHEN, X.B.; Mac LEOD, N.A. et al. Excretion of purines derivatives by ruminants effect of microbial nucleic acid infusion on purine derivative excretion by steers. Journal Agricultural Science, v.114, p.243-248, 1990.
VERBIC, J. Factors affecting microbial protein synthesis in the rumen with emphasis on diets containing forages. Viehwirtschaftliche Fachtagung, Milchproduktion und Rindermast. Gumpenstein, Germany: 2002. p.1-10.

WALLACE, R.J. Ecology of rumen microorganism: protein use. In: INTERNATIONAL CONGRESS OF THE INTERNATIONAL UNION OF PHYSIOLOGICAL SCIENCES, 30., 1988, Ithaca. Proceedings... Ithaca: Cornell University. Press, 1988. p.99-123.

WISEMAN, J. El procesado de cereales en dietas de monogástricos. IX Curso de Especialización FEDNA. Barcelona: FEDNA, 1993.

YAN, T.; OFFER, N.W.; ROBERTS, D.J. The effects of dietary nitrogen sources and levels on rumen fermentation, nutrient degradation and digestion and rumen microbial activity by wether sheep given a high level of molasses. Animal Science, v.63, p. 123-131, 1996.

YANG, C.M.; RUSSELL, J.B. The effects of monensin supplementation on ruminal ammonia accumulation in vivo and the numbers of amino acid-fermenting bacteria. Journal of Animal Science, v.71, p.3470-3476, 1993.

YU, P.; EGAN, A.R.; LEURY, B.J. Protein evaluation on dry roasted whole faba bean (Vicia faba) and lupin seeds (Lupin albus) by the new dutch protein evaluation system: the DVE/OEB system. Asian Australasian Journal of Animal Science, v.12, n.6, p.871-880, 1999.

YU, P.; GOELMAN, J.O; TAMMINGA, S. Using the DVE/OEB model to determination optimal conditions of pressure toasting on horse beans (Vicia faba) for dairy feed industry. Animal Feed Science and Technology, v.86, p.165-176, 2000.

YU, P.; LEURY, B.J.; SPRAGUE, M. et al. Effect of the DVE and OEB value changes of grain legumes Lupin and Faba beans after roasting on the performance of lambs fed a roughage-based diet. Animal Feed Science and Technology, v.94, p.89-102, $2001 \mathrm{a}$.

YU, P.; BOON-EK; L., LEURY, B.J. et al. Effect of dietary protein variation in term of net truly digest intestinal protein (DVE) and rumen degraded protein balance (OEB) on the concentration and excretion of urinary creatinine, purine derivatives and microbial $\mathrm{N}$ supply in sheep: comparation with the prediction from the DVE/OEB model. Animal Feed Science and Technology, v.93, p.71-91, 2001b.

YU, P.; GOELEMA, J.O.; LEURY, B.J. et al. An analysis of the nutritive value of heat processed legume seeds for animal production using the DVE/OEB model: a review. Animal Feed Science and Technology, v.99, p.141-176, 2002a.

YU, P.; EGAN, A.R.; BOON-EK, L. et al. Purine derivative excretion and ruminal microbial yield in growing lambs fed raw and dry roasted legume seeds as protein supplements. Animal Feed Science and Technology, v.95, p.33-48, 2002b.

YU, P. Protein molecular structures, protein subfractions, and protein availability affected by heat processing: a review. American Journal Biochemistry and Biotechnology, v.3, n.2, p.66-86, 2007.

ZINN, R.A.; BULL, L.S.; HEMKEN, R.W. Degradation of supplemental proteins in the rumen. Journal of Animal Science, v.52, n.4, p.857-866, 1981. 